\title{
ANALISIS GAMBAR KARYA ANAK SEKOLAH DASAR (KARAKTERISTIK GAMBAR ANAK USIA 7 - 9 TAHUN)
}

\author{
Ira Rengganis \\ Universitas Pendidikan Indonesia \\ rengganisira@yahoo.co.id
}

\begin{abstract}
The writing is motivated by the author's interest in the work of drawings made by children. In this paper, the image being analyzed is the work of drawings made by children aged 7 to 9 years of age or elementary school students grades 1 to 3. This research aims to know the functions and characteristics of the child in learning colleges Arts. In this study used methods of art criticism. Art criticism method consists of several stages, namely the stages of description, formal analysis, interpretation and final stage of assessment. Through the process of analysis methods of art, criticism can be concluded that the draw for children is as a medium to develop a proper sense, expression, imagination and visual communication. Arts education; Arts in children's education has an important role as an introduction and training efforts the power of expression, imagination, creativity, and artistic taste esthetics in an atmosphere of creative play. Stock images of children aged 7 to 9 have the unique characteristics of various types and properties of different images. In order to achieve the purpose of art education in elementary schools, in addition to the necessary active learning, innovative, creative, effective and fun, in the learning activities of art is in need of a teacher who understands its function in performing the procedure of learning and understanding the characteristics of children's drawings.
\end{abstract}

Keywords: drawing, children aged 7-9 years, the image characteristics of children

\section{A. PENDAhuluan}

Pembelajaran Seni Rupa di sekolah mengembangkan kemampuan siswa dalam berkarya seni yang bersifat visual dan rabaan. Pembelajaran seni rupa memberikan kemampuan bagi siswa untuk memahami dan memperoleh kepuasan dalam menanggapi karya seni rupa ciptaan siswa sendiri maupun karya seni rupa ciptaan orang lain.

Melalui pengalaman berkarya, siswa memperoleh pemahaman tentang berbagai penggunaan media, baik media untuk seni rupa dwimatra maupun seni rupa trimatra. Dalam berkarya seni rupa, siswa belajar menggunakan berbagai teknik tradisional dan modern untuk mengeksploitasi sifatsifat dan potensi estetik media. Melalui seni rupa, siswa belajar berkomunikasi melalui gambar dan bentuk, serta mengembangkan rasa kebanggaan dalam menciptakan ungkapan pikiran dan perasaannya.
Materi pokok seni rupa meliputi aspek apresiasi seni, berkarya seni, kritik seni, dan penyajian seni. Apresiasi seni rupa berarti mengenal, memahami, dan memberikan penghargaan atau tanggapan estetis (respons estetis) terhadap karya seni rupa. Materi apresiasi seni pada dasarnya adalah pengenalan tentang konsep atau makna, bentuk, dan fungsi seni rupa. Apresiasi seni rupa dapat mencakup materi yang lebih luas, yaitu pengenalan seni rupa dalam konteks berbagai kebudayaan.

Pembahasan konsep seni rupa meliputi struktur bentuk dan ungkapan (ekspresi) dalam seni murni dan hubungan bentuk, fungsi, dan elemen estetik dalam seni rupa terapan. Pembahasan tentang media seni rupa meliptui ciri-ciri media, proses, dan teknik pembuatan karya seni rupa. Selain itu, apresiasi seni juga perlu memberikan pemahaman hubungan antara seni rupa 
dengan bentuk-bentuk seni yang lain, bidang-bidang studi yang lain, serta keberadaan seni rupa, kerajinan, dan desain sebagai bidang profesi.

Salah satunya dengan cara menggambar. Menggambar adalah aktivitas kreatif untuk menyalurkan dan menggambarkan ekspresi seseorang yang membuatnya. Begitu pula bagi anak-anak. Anak-anak memiliki penilain dan cara pandang sendiri terhadap objek yang digambarnya. Hal ini hanya terjadi bila sang anak memiliki orisinalitas dan spontanitas pada gambarnya. Akan berbeda bila sejak awal sang anak telah di ajari menggambar dengan karakter orang dewasa dan menerapkan pola-pola gradasi saat mewarna. Anak-anak yang belajar pada satu sanggar seperti itu sudah dipastikan tidak memiliki jati diri pada karyanya sebab antara satu anak dengan anak yang lainnya akan memiliki kesamaan karakter baik gambar maupun warna selain itu menggambar seperti ini akan menemukan titik jenuh sebab proses berkarya yang berpola mengakibatkan tidak berkembangnya karakter gambar yang telah dibuatnya. Berbeda jika anak dibina untuk tetap mempertahankan originalitas gambarnya sehingga kemungkinan untuk berkembang saat mengalami peralihan dari masa anak, remaja kemudian dewasa akan lebih terbuka.

\section{B. KAJIAN LITERATUR}

Menurut In Education Through Art, Read (1958: 140) penggambaran objek bersifat realistis, tetapi tidak bergerak seperti organik juga objek yang digambarkan statis. Pada gambar ini juga terdapat pola rytmis dimana ada pengulangan objek seperti padi di sawah, bunga-bunga di kebun dan beberapa pohon di bawah kaki gunung.

Anak berusia 9 tahun termasuk ke dalam masa bagan,dimana anak mampu menggambar bentuk dan warna objek cenderung sesuai dengan aslinya. Menurut Lansing (Kamaril : 1999:2.38) periode perkembangan anak - anak ini tergolong kedalam pertengahan figuratife tetapi menurut Viktor Lowenfeld dan Lambert
Britanny termasuk ke dalam masa realism awal. Untuk memahami dan menafsirkan makna suatu peristiwa dalam situasi tertentu menurut teori dan analisis. Pendekatan keilmuan Estetika, kemudian menggunakan metoda Kritik Seni untuk memahami visualisasi karya, yang mengacu pada buku yang ditulis Edmund Burke Feldman yaitu Art as Image and Idea (Feldman, 1967).

\section{METODE PENELITIAN}

Penelitian ini merupakan jenis penelitian kualitatif. Untuk memahami dan menafsirkan makna suatu peristiwa dalam situasi tertentu menurut teori dan analisis. Pendekatan keilmuan Estetika, kemudian menggunakan metoda Kritik Seni untuk memahami visualisasi karya, yang mengacu pada buku yang ditulis Edmund Burke Feldman yaitu Art as Image and Idea (Feldman, 1967) mencakup beberapa tahapan, yaitu:

1. Tahapan Deskripsi (Description) Deskripsi meliputi:

a. Membuat daftar tentang apa saja yang kita lihat dalam sebuah karya; DAN

b. Menyajikan sebuah analisis secara teknis tentang bagaimana karya tersebut dibuat.

2. Tahapan Analisis Formal.

Dalam analisis bentuk, kita mencoba untuk berada "lebih dalam" dari sekedar menjelaskan secara detail tentang proses berkarya.Pada analisis bentuk, kita tidak lagi terikat pada hal-hal yang bersifat teknis, tetapi dalam analisis bentuk, kita lebih terfokus pada hal-hal yang artistik, seperti kualitas garis, bentuk, warna, pencahayaan, dan lain-lain.

Analisis bentuk membutuhkan pengalaman dan pemahaman visual kita tentang bentuk, arah, warna, garis, serta ilusi visual ketika mengamati sebuah karya seni. 
Analisis bentuk akan membantu kita dalam menetapkan penafsiran kita dan membantu kita dalam memberikan penilaian tentang sebuah karya.

Dalam membuat analisis bentuk, kita telah mengakumulasikan buktibukti visual yang akan membantu kita untuk melakukan penafsiran terhadap karya tersebut dan melakukan penilaian terhadap keadaan terkini.Pada analisis bentuk, kita mulai bergerak dari bentuk yang sudah kita deskripsikan secara obyektif pada bagaimana cara kita merasakan bentuk tersebut.

3. Tahapan Interpretasi (Intepretation)

Penafsiran merupakan salah satu bentuk kritik yang beusaha mencari makna atau arti dari sebuah karya.

Penasiran bukan sebuah usaha untuk memberikan penilaian terhadap suatu karya, tetapi suatu bentuk usaha untuk menemukan tentang apa yang ingin diungkapkan oleh seorang seniman (anak) melalui karyanya.

4. Tahapan Penilaian

Dalam tahap Penilaian ini, merupakan tahap akhir dari menganalisis gambar karya anak. Salah satunya untuk menilai karya apakah karya anak yang diteliti merupakan karya seni yang benar-benar murni hasil ekspresi anak.

Dalam penelitian ini, tidak menutup kemungkinan bidang keilmuan lainnya seperti psikologi akan mendukung pula metodologi penelitian, yang diharapkan dapat mengungkapkan apa yang ingin disampaikan anak melalui karya.

\section{HASIL DAN PEMBAHASAN}

Analisis Gambar Karya Anak UsiaTahun

\section{Nama : Salman Alfarizi \\ Usia : 7 Tahun \\ L/ P : Laki-laki}

Tema :

Tema pada gambar ini adalah cityscape dimana pada gambar ini menggambarkan salah satu sudut diperkotaan. Salah satu cirinya dengan banyaknya rumah-rumah dan ada juga kebun binatang. a. Bentuk/ simbol

1) Gambar rumah terlihat realistis, dari mulai Pintu, jendela, atap rumah, pagar dan dindingnya. Namun masih belum terlihat sempurna dan ada juga beberapa rumah yang jendela atau pintu.

2) Pohon juga hampir menyerupai aslinya ada batang dan daundaunnya. Namun belum terlihat sempurna karena terlihat daun yang hilang di tengahtengah pohon tersebut.

3) Bentuk gunungnyapun menyerupai aslinya, terjadi pengulangan bentuk namun kurang sempurna karena tidak ada tekstur dari gunung.

4) Gambar matahari yang cerah dan bulat sempurna menandakan bahwa keadaan pada gambar itu siang hari,karena matahari berada tepat diatas dan disampingnya ada awanawan yang cerah.

5) Gambar manusia memang belum sempurna, namun anak sudah mengerti bahwa manusia itu memiliki kepala,badan,tangan,kaki,da $n$ rambut.

6) Jalan raya memang terlihat sederhana, namun anak sudah mengerti konsep membuat jalan, jika semakin jauh itu jalan semakin kecil atau sempit.

7) Gambar layang-layang sudah menyerupai bentuk aslinya, hanya saja memang kurang seimbang bentuk ketupatnya.

b. Garis

1) Garis pada pembuatan gambar awan terlihat spontan, tidak ragu-ragu. Namun pada proses 
pewarnaannya spontan juga tapi putus-putus dan tidak searah.

2) Garis pada pembuatan matahari terlihat spontan dan tegas, proses pewarnaannya terlihat spontan dan tidak searah.

3) Pada pembuatan gunung, garis terlihat ragu-ragu karena ada garis yang diulang, dan pada proses pewarnaannya ada sebagian yang spontan dan sebagian lagi terlihat putus-putus dan ragu-ragu.

4) Garis pada pembuatan bangunan atau rumah-rumah terlihat tegas. Namun pada proses pewarnaannya masih terlihat ragu-ragu dan tidak searah.

5) Garis pada pembuatan pohon terlihat tegas, namun pada proses pewarnaannya masih terlihat raguragu.

6) Garis pada pembuatan orang terlihat tegas dan spontan. Dan pada proses pewarnaannyapun terlihat spontan.

7) Garis pada pembuatan jalan terlihat spontan dan dipertegas lagi dengan pengulangan pembuatannya atau di tebalkan lagi.

8) Garis pembuatan layang-layang terlihat spontan.

9) Garis pembuatan tiang-tiangnya ada yang terlihat tegas dan ada juga yang ragu-ragu.

c. Warna

Pada gambar ini banyak sekali warna yang digunakan. Namun ditinjaudari keseluruhan warna pada gambar ini yang paling dominan adalah warna biru, terlihat dari warna awan, gunung, layang-layang dan hampir semua rumah salah satu bagiaannya adalah warna biru. Warna biru termasuk dalam warna dingin atau memberikan kesan tenang dan mendekatkan keinginan.

Selain warna biru juga ada warna merah yang sering digunakan. Warna merah termasuk ke dalam warna hangat. Warna merah melambangkan kesan energi, kekuatan, keberanian, dan kehangatan.Warna ini dapat menyampaikan kecenderungan untuk menampilkan gambar dan teks secara lebih besar dan dekat.

Selanjutnya ada warna coklat yang mengandung arti menunjukan persahabatan, kedamaian, kepercayaan, praktis, dan kesenangan. Warna coklat termasuk pada warna netral.

Lalu ada juga warna hijau yang menunjukan kesan alami, sehat, keberuntungan dan keseimbangan. Warna hijau dapat digunakan untuk relaksasi karena dapat menenangkan pikiran. Warna hijau termasuk pada kelompok warna sejuk atau dingin.

Warna selanjutnya yang digunakan ialah warna ungu.Warna ungu termasuk kedalam kelompok warna hangat.Warna ungu memberikan kesan menunjukkan pengaruh,pengetahuan yang tersembunyi, pencerahan, dan kepercayaan yang dalam.

Ada juga warna kuning yang termasuk pada kelompok warna hangat. Warna kuning menunjukan kegembiraan, sosial, kehormatan, loyalitas, kerjasama, dan optimisme. Warna Kuning merangsang aktivitas mental dan menarik perhatian.

Warna orange termasuk pada kelompok warna hangat atau warna yang memberikan kesan berani atau energik, warna orange menunjukan kehangatan, kesuksesan, kesehatan pikiran, keadilan dan kegembiraan.

Dan selanjutnya adalah warna merah muda yang 
menunjukan simbol kasih sayang, damai, perasaan yang halus dan indah. Warna merah muda termasuk pada kelompok warna hangat.

d. Komposisi

1) Kesatuan (unity). Karena terdapat berbagai unsur dengan karakter yang berbeda.

2) Keseimbangan (balance) Simetris. Gambar gunung dan rumah-rumah diletakan dalam susunan yang sama. Gunung diatasnya dan rumah dibawah.

e. Tipe

Tipologi gambar anak Tipe gambar tersebut visual atau bentukbentuknya disusun sesuai dengan cerita.

f. Jenis

Gambar tersebut berpola rytmis, yaitu adanya pengulangan objek yang dilihat. Seperti gunung, awan, orang, layang-layang, termasuk bangunan rumah pada gambar. Gambar tersebut juga berpola xray, terletak pada gambar batang pohon yang terlihat transparan.

Dan Gambar rumah-rumah juga berpola bersusun.

g. Deskripsi gambar

Menurut Viktor Lowenfeld dan Lambert Brittain periode perkembangan seni rupa anak-anak pada usia 4-7 tahun adalah masa prabagan, yaitu Anak sudah mulai menggambar obyek dalam suatu hubungan yang logis dengan gambar lain. Konsep ruang mulai nampak dengan adanya pengaturan antara hubungan obyek dengan ruang, gambar mulai realistis, mulai mengarah ke bentuk-bentuk yang mendekati kenyataan.Kesan ruang pada gambar tersebut penumpukan, terlihat dari gambar rumah yang sangat padat. Warna pada gambar full colour, menandakan suasana hati anak sedang gembira. Pada penggambaran jalan anak sudah mengerti konsep bahwa pemberian kesan jauh itu semakin jauh semakin menyempit. Keseluruhan gambar cukup realistis dari gambar gunung, awan, matahari, rumah, pohon, orang, dan layanglayangnyapun hampir menyerupai aslinya. Dengan menggambar jenis penumpukan seperti ini, sepertinya anak penuh dengan imajinasi, dia bisa merealisasikan apa yang pernah ia lihat dalam kehidupannya. Dengan menggunakan banyak warna sepertinya tipe anak ini periang. Gambar berpola rytmis karena banyak pengulangan pada pembuatan bentuk-bentuk, seperti gambar gunung, awanawan, orang-orang yang ada pada gambar dan tipe rumah yang hampir sama.

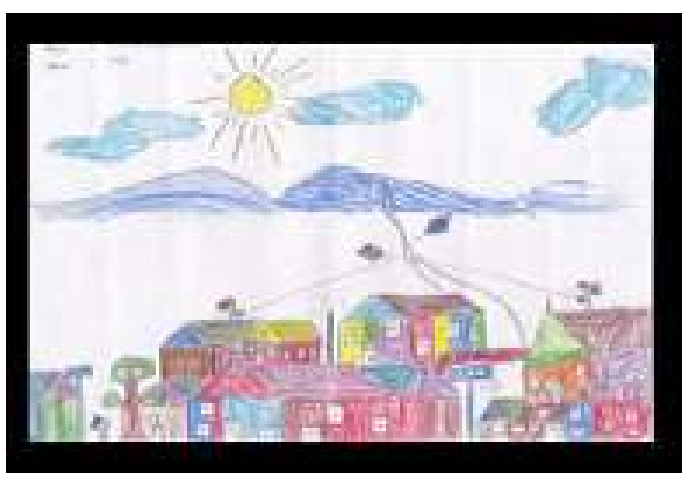

Gambar 1

Karya Salman Alfarizi

2. Nama : Zakaria Al-Ansari

Usia : 7 Tahun

L/P : Laki-laki

Tema : Beristirahat

a. Bentuk / Simbol

Dalam gambar tersebut terdapat suasana di padang rumput, lalu ada orang yang sedang duduk diatas kayu sambil menjulurkan tangannya, didepannya terdapat api yang digunakan untuk memasak air. 
Airnya sudah mendidih hingga mengeluarkan uap/asap. Kemudian didepannya terdapat kuda. Lalu ada dua pohon, satu pohon disamping kanan dan satunya lagi ada disamping kiri. Ada sebuah rumah, matahari, langit dan ada bukit juga.

1) Orang. Orang disini terlihat seperti sedang beristirahat, karena digambarkan dalam posisi duduk dan tangan menjulur kedepan.

2) Kuda. Kuda sedang istirahat karena posisinya digambarkan dalam keadaan ditali ke pohon dan sedang diam.

3) Rumah. Bentuknya seperti jamur, hanya saja ada pintu dan jendela, gentengnya tidak berbentuk lancip/segitiga tapi berbentuk setengah lingkaran.

4) Padang rumput. Tak ada gambar rumputnya tapi karena warnanya hijau, sperti padang rumput yang terhampar luas.

5) Uap/asap. Digambar tepat diatas panci dan digambar sedikit miring. Kesannya seperti asap yang tertiup angin.

6) Panci. Digambarkan sedang digantung diatas api, maksudnya disini adalah sedang memasak.

7) Kayu yang terbakar/api. Digambar di bawah panci, sama seperti api unggun. Hanya saja ada panci diatasnya.

8) Pohon. Digambar seperti aslinya, ada tangkai dan ada daun yang rindang. Ada dua pohon, tetapi berbeda jenis. Salah satunya adalah pohon kelapa, terlihat ada buahnya yang agak lonjong dan banyak menggantung di pohon.

9) Jalan. Digambar seperti jalan yang tidak diaspal, melintang melewati rumah.

10) Matahari dan langit. Dari gambarnya, menunjukan keadaan siang yang menuju sore karena dari warna langit yang biru dan warna matahari orange yang tidak terlalu cerah. Matahari terhalangi oleh bukit, jadi hanya terlihat sepertiganya saja.

11) Bukit. Digambarkan berendenganan dengan langit. Pembatasnya adalah garis coklat yang melengkung-lengkung.

b. Garis

1) Orang beserta sepatunya. Digambar dengan garis yang raguragu tetapi akhirnya dipertegas. Karena garisnya dipertebal namun tidak rapih.

2) Tempat duduk kayu. Digambar dengan garis yang raguragu dan tegas.

3) Uap/asap. Digambar dengan garis yang spontan.

4) Api dan kayu bakarnya. Digambar dengan garis yang spontan, tetapi pada saat garis pada kayu bakarnya terdapat sedikit keraguan.

5) Panci dan gantugannya. Garis yang dicoretkan, secara spontan. Tapi gantungannya digambar dengan garis yang ragu-ragu.

6) Kuda

Digambar dengan garis yang raguragu, terlihat dari garisnya yang tipis dan kkurang tegas. Kecuali pada ekor kuda, dan dan tali yang mengikatnya digambar dengan garis spontan.

7) Jalan Digambarkan dengan garis yang spontan, karena garisnya melintang dari uung ke ujung.

8) Rumah. Digambar yang dengan garis yang spntan, tapi ada sedikit keraguan.

9) Pohon Ada dua pohon yang digambarkan, satu pohon yang seperti beringin digambarkan dengan garis 
yang spontan dan garis putusputus di akarnya.. Sedangkan untuk pohon kelapa, digambarkan juga dengan garis yang spontan tetapi saat penggambaran pelepahnya yang diberi garis putus-putus.

10) Langit dan matahari Keduanya digambar spontan dan tegas, bisa dilihat dari cara pewarnaan-nya yang tidak ragu dan tegas.

11) Bukit Digambarkan dengan garis yang tegas.

c. Warna

Gambar ini didominasi oleh warna hijau, yang memberi makna kesuburan. Karena warna hijau disini memberikan kesan bahwa orang yang digambarkan berada di padang rumput yang subur dan tidak gersang. Pohon-pohonnya yang daunnya berwarna hijau memberikan kesan subur dan batangnya yang berwarna cokelat memiliki makna kedamaian seolah memberi kesenangan bagi ada yang di dekatnya. Kuda yang berwarna cokelat melambangkan kuda yang memiliki kekebalan dan kuat serta melambangkan persahabatan, maksudnya adalah bersahabat dengan pemiliknya. Gambar orang yang diberi baju warna merah melambangkan bahwa orang itu adalah seorang pemberani dan tidak takut akan resiko, sepatunya yang berwarna cokelat melambangkan kestabilan dan menambah kesan elegan. Langit yang berwarna biru mengungkapkan bahwa si penggambar sedang kreatif dan memberi inspirasi, sedangkan warna biru langit pada gambar memberikan rasa nyaman dan kecerahan saat hari itu (pada gambar). Matahari yang berwarna jingga, mempunyai makna persahabatan yang berarti hari itu (pada gambar) memberikan kesan yang tenang dan damai. Api yang diberi warna merah artinya api itu panas dan sedang menyala. Kayu yang sedang diduduki berwarna cokelat, melambangkan sifat yang membumi dan menghadirkan kenyamanan bagi siapa saja yang duduk diatasnya. Jalan yang melintang melewati rumah, diberi warna cokelat karena memberi kesan natural, bahwa jalan tersebut belum di aspal layaknya jalan di pedesaan.

d. Komposisi

Komposisi gambar simetris karena ada dua buah pohon. Yang satu berada di sisi kanan, dan yang satu lagi berada di sisi kiri gambar. Tak ada ruang yang kosong, semuanya sudah penuh oleh warna. Jadi saya menyimpulkan bahwa gambar ini simetris.

e. Tipe

Gambar ini bertipekan visual, karena orang yang melihatnya akan tau maksud dari gambar tersebut. Dan objek yang digambarkan mudah untuk ditebak. Seperti gambar kuda yang sedang diikatkan, orang yang sedang duduk, api yang sedang meyala, langit, matahari, rumah, pohon.

f. Jenis

Gambar ini berjenis Organik karena berkaitan dengan objekobjek nyata dan ada hubungan organis yang wajar. Ini ditunjukan dengan adanya gambar pohon yang menjulang, adanya manusia, hewan, serta ada gambar rumah. Semuanya memiliki keterkaitan satu sama lain.

g. Deskripsi

Pada siang hari ada seorang pemilik kuda yang sedang beristirahat di padang rumput dekat rumahnya dan duduk di 
sebuah kayu sambil menunggu masakannya matang. Dia mengikatkan kudanya ke sebuah pohon agar tidak kabur. Alamnya begitu subur dan udaranya begitu sejuk. Lalu pemilik kuda itu akan mengecek apakah masakannya sudah matang atau belum.

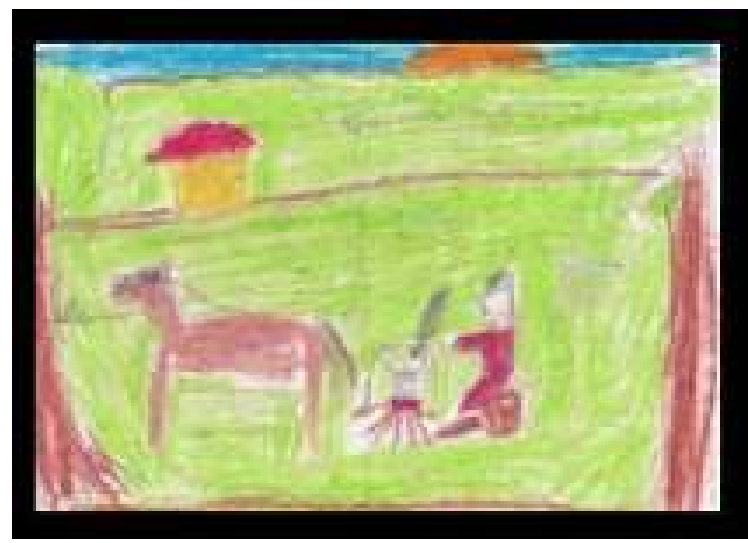

Gambar 2

Karya Zakaria Al-Ansari

3. Nama : Sopian

Usia : 7 Tahun

L/P : Laki-laki

Tema : Pemandangan alam

a. Bentuk/Simbol

Di dalam gambar tersebut terdapat pengulangan bentuk dan mempunyai simbol-simbol diantaranya:

1) Layangan mempunyai sebuah simbol seorang laki-laki yang berkuasa di atas segalanya.

2) Kupu-kupu mempunyai arti mencintai keindahan dan menginginkan suatu kebebasan.

3) Pelangi mempunyai arti kehidupan yang berbahagia dan bermakna.

4) Matahari selalu menyinari dunia artinya ingin selalu berguna bagi orang lain dan berambisi. Dan,

5) Ikan tidak bisa hidup tanpa air dan memiliki simbol selalu bersosialisasi.

b. Garis

Macam-macam garis sangat bervariasi di dalam gambar tersebut terlihat jelas menggunakan garis terputus-putus dan ragu-ragu karena setiap gambar memiliki bentuk yang bervariasi. Garis merupakan sebuah titik penghubung untuk menyatukan menjadi sebuah bentuk.

c. Warna

Pada gambar ini tidak terlalu banyak menggunakan warna dalam sebuah karya tersebut, di dalam karya tersebut dominan menggunakan warna hijau muda, menurut analisis saya warna hijau muda menggambarkan suatu perasaan yang tenang, dan mencintai kedamaian dan ketentraman. Dan biasanya mempunyai rasa dingin dan impersonal.

\section{d. Komposisi}

Di lihat dari komposisi warnanya sangat sederhana dan tidak menggunakan banyak warna. Dan bentuknya juga transparan. Anak membuat objek gambar bila objeknya lebih dari satu atau jamak, biasanya dikomposisikan dangan cara berlapis-lapis dari atas ke bawah. Objek yang letaknya jauh digambar dengan letak di atas objek yang lebih dekat.Benda yang lebih jauh digambarkan lebih kecil dibanding benda yang lebih dekat dari pandangan mata.

Di dalam gambar tersebut juga terdapat komposisi rebahan dan komposisi belahan. Komposisi rebahan yaitu objek gambar dibuat seperti roboh atau terguling, jadi seakan objek tidak berdiri. Sedangkan komposisi belahan yaitu komposisi yang membagi 2 bidang gambar kanan dan kiri. Jadi objek gambar diletakkan di posisi kanan dan kiri bidang gambar.Komposisi belahan membuat ruang terbelah 
menjadi 2 yaitu ruang kanan dan ruang kiri.objek yang lebih dekat biasanya diletakkan di belahan kiri kertas dan objek yang jauh berada di sebelah kanan kertas, dengan tidak ada pertimbangan sudut pandang perspektif.

e. Tipe

Di lihat dari tipenya, gambar anak tersebut termasuk ke dalam tipe visual, karena kemampuan daya tangkap atau indra sangat menonjol sehingga anak mampu merekam objek aslinya termasuk proporsi, perpektif, perbandingan serta detailnya. Dan bentuknya mudah diidenfikasikan oleh orang lain dan hanya sekedar menyusun bentuk sederhana.

Dan biasanya pada masa usia 8 tahun termasuk kedalam masa bagan, yaitu mereka akan sering mengulangngulang bentuk, namun tetap pada masa ini anak belum mengembangkan konsep ruang pada karyanya, sehingga gambar mereka masih berkesan datar tidak memiliki kedalaman.

Dan biasanya anak berfikir bahwa semua objek harus digambarkan secara tegak lurus dengan dasar atau bidang tempat objek tersebut terpijak. Bila bidang pijakan horizontal itu tak terlihat aneh, tetapi bila bidang pijakannya memiliki kemiringan seperti jalan yang ada pada gambar, yang di atasnya pohon maka akan selalu tegak lurus dengan yang dipijaknya.

f. Jenis

Gambar ini termasuk ke dalam jenis realisme karena menekankan pada realitas sehari-hari, dan menggambarkan atau meniru keadaan alam secara akurat dan jujur tidak ditutup tutupi, realisme menampilkan subjek apa adanya, tanpa embel-embel bahkan tanpa interpretasi. g. Deskripsi

Di dalam gambar yang sudah di analisis bertemakan pemandangan alam, dimana didalamnya terdapat dua gunung, sebuah rumah, jalan, pohonpohon, ada kolam ikan, dan di atas langit ada matahari yang di hiasi pelangi dan kupukupu. Gambar ini termasuk kedalam tipe visual karena menirukan situasi alam nyata yang dilihat dalam kehidupan sehari-hari meskipun menirunya belum seperti sama dengan yang aslinya. Komposisi warna dan latarnya juga masih sangat sederhana tapi terdapat bentuk atau simbol-simbol yang bermakna menggambarkan sifat atau karakter anak yang menggambarnya.Gambar

tersebut tidak terlalu banyak warna hanya dominan warna hijau.

Suatu karya seni rupa tidak ada yang terlihat bagus atau jelek, semuanya tergantung dari penggambarnya dan relatif. Hasil karya seni rupa bisa menjadikan sebuah perwakilan hati atau perasaan atau hanya keinginan pembuatnya.

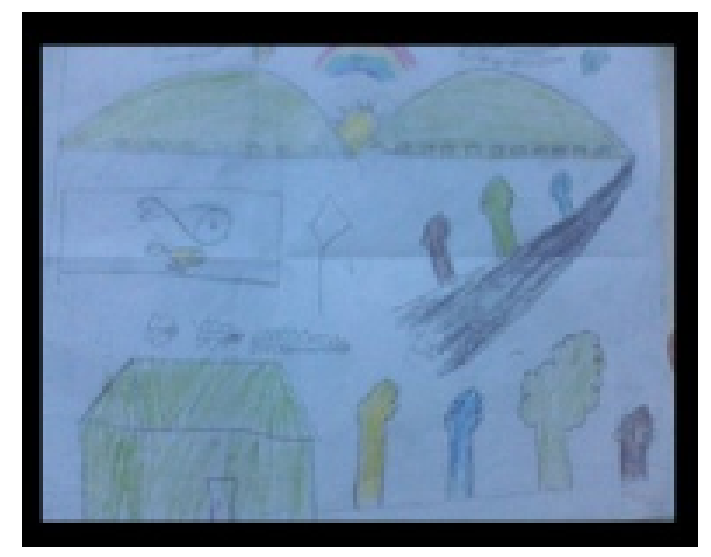

Gambar 3

Karya Sopian

Analisis Gambar Karya Anak Usia 8 Tahun 
1. Nama : Syahlaa

Usia : 8 tahun

L / P : Perempuan

Tema :

Tema dari gambar yang saya analisis adalah perumahan. Tema tersebut cukup sesuai dengan hasil gambar yang tampak, karena ditandai dengan adanya gambar sebuah rumah yang bermaksud menunjukkan bahwa gambar itu bertempat di halaman sebuah rumah yang berada di dalam tema tersebut yaitu perumahan.

\section{a. Bentuk/simbol}

Berbagai karya seni rupa di sekeliling kita memiliki banyak macam ragamnya. Keragaman tersebut dapat terlihat dari bentuknya, warnanya, bahan bakunya, alat pembuatannya, fungsinya atau pemanfaatannya. Kita dapat membedakan bentuk karya seni rupa berdasarkan dimensi dan kegunaan atau fungsinya.

Berdasarkan dimensinya, karya seni rupa terbagi menjadi dua yaitu karya seni rupa dua dimensi dan karya seni rupa tiga dimesi. Karya seni rupa dua dimensi merupakan karya seni rupa yang memiliki dua ukuran (panjang dan lebar) sedangkan karya seni rupa tiga dimensi memiliki tiga ukuran (panjang, lebar, dan tebal) atau memiliki ruang.

Berdasarkan kegunaan atau fungsinya, karya seni rupa digolongkan ke dalam karya seni murni dan karya seni pakai. Seni murni adalah karya seni yang diciptakan semata-mata untuk dinikmati keindahan atau keunikannya saja, tanpa atau hampir tidak memiliki funsi praktis.Adapun seni pakai adalah karya seni rupa yang prinsip pembentukannya mengikuti fungsi tertentu dalam kehidupan sehari-hari.
Simbol. Simbol yang terdapat pada gambar ini adalah simbol yang menjelaskan atau menunjukkan waktu pada siang hari yaitu berupa gambar matahari dan awan. Gambar matahari disana, dibuat menyerupai wajah manusia yang sedang tersenyum, itupun bermaksud menjelaskan bahwa matahari memberikan kehidupan, memberikan pencerahan, dan memberikan kebahagiaan bagi makhluk hidup.

b. Garis

Garis merupakan unsur mendasar dan unsur penting dalam mewujudkan sebuah karya seni rupa. Perwujudan karya seni rupa pada umunya diawali dengan coretan garis sebagai rancangannya. Garis memiliki dimensi memanjang dan mempunyai arah serta sifat-sifat khusus seperti pendek, panjang, vertikal, horizontal, luris, melengkung, berombak, dll. Garis dapat terjadi karena titik yang bergerak membekaskan jejaknya pada sebuah permukaan benda.

Dalam sebuah karya seni rupa, garis dapat juga digunakan sebagai simbol ekspresi.Garis tebal tegak lurus misalnya, memberi kesan kuat dan tegas, sedangkan garis tipis melengkung member kesan lemah dan ringkih. Karakter garis yang dihasilkan oleh alat yang berbeda akan menghasilkan karakter yang berbeda pula.

Pada gambar yang saya analisis, garis yang tampak masih terlihat ragu-ragu. Keraguraguan tersebut dapat dibuktikan dengan banyaknya bekas hapusan karena garis yang awalnya salah. Garis yang 
terdapat pada gambar juga ada yang tidak tegak lurus, tetapi masih bengkok/miring yang disebabkan oleh keragu-raguan si anak tersebut dalam menggambar.

c. Warna/Makna

Warna pada dasarnya merupakan kesan yang timbul akibat pantulan cahaya yang mengenai permukaan suatu benda. Menurut teori warna Brewster, semua warna yang ada berasal dari tiga warna pokok (primer) yaitu merah, kuning, dan biru. Pencampuran dua warna primer akan menghasilkan warna sekunder dan bila dua warna sekunder dicampurkan akan menghasilkan warna tersier.

Pada gambar ini terdapat sebuah rumah dengan dinding berwarna oren, jendela berwarna putih, atap berwarna cokelat, dan pintu berwarna ungu. Selain itu, Terdapat pula tumbuhan yaitu bunga berwarna merah, daun berwarna hijau, serta pohon dengan daun berwarna hijau dan batang berwarna coklat. Disamping itu, terdapat pula matahari berwarna kuning, dan awan berwarna biru. Hal ini menunjukkan bahwa penggunaan warna pada gambar tersebut yaitu harmonis yang artinya penerapan warna sesuai dengan kenyataan.

d. Komposisi

Prinsip-prinsip seni rupa berupa kaidah atau aturan baku yang diyakini oleh beberapa seniman secara konvensional dapat membentuk sebuah karya seni yang baik dan indah. Kaidah dan aturan baku ini disebut komposisi. Komposisi mencakup tiga bagian pokok yaitu kesatuan (unity), keseimbangan (balance), dan irama (rhythm).

Prinsip komposisi kesatuan ditunjukkan dengan penataan berbagai objek yang terdapat dalam sebuah karya seni. Dalam gambar ini, terdapat komposisi yang mebentuk kesatuan yaitu dengan adanya gambar bunga yang diiikuti dengan gambar pohon serta gambar matahari yang diikuti dengan gambar awan.

Keseimbangan merupakan penyusunan unsur-unsur yang berbeda atau berlawanan tetapi memiliki keterpaduan dan saling mengisi atau menyeimbangkan. Keseimbangan ini ada yang simetris dan adapula yang asimetris. Pada gambar ini, keseimbangan yang ditunjukkan yaitu simetris artinya menunjukkan atau menggambarkan beberapa unsur yang sama diletakkan dalam susunan yang sama (kiri-kanan, atas-bawah, dll). Ini ditunjukkan dengan posisi gambar bunga dan pohon yang mengisi bagian kiri dan kanan.

Irama dalam seni rupa merupakan kesan gerak yang timbul dari penyusunan atau perpaduan unsurunsur seni dalam sebuah komposisi. Pada gambar ini, kesan irama belum ditunjukkan karena mengingat usia si anak yang masih melihat/menggambar bendabenda sesuai dengan apa yang dilihatnya dan belum menggunakan rasa yang dapat menimbulkan kesan irama tersebut.

e. Tipe

Terdapat dua jenis tipologi gambar anak, yaitu tipe visual/nonhaptik/realistis dan tipe haptik. Tipe visual yaitu gambar yang mudah diidentifikasi oleh orang lain dan bentuk disusun sesuai dengan cerita/hanya sekedar menyusun bentuk sederhana. Tipe haptik 
cenderung

mengungkapkan/mengekspresikan

perasaan atau pikiran daripada

kejelian bentuk-bentuknya.

Tipe dari gambar yang saya analisis adalah tipe visual. Ini dibuktikan dengan gambar anak yang bertema perumahan dengan adanya gambar rumah dan halamannya sesuai dengan apa yang sering dilihat oleh si anak.

f. Jenis

Salah satu jenis karya seni rupa adalah seni lukis. Seni lukis merupakan kegiatan pengolahan unsur-unsur seni rupa seperti garis, bidang, warna dan tekstur pada bidang dua dimensi.

Adapun gambar anak yang saya analisis ini merupakan salah satu contoh seni lukis sederhana.Salah satu jenis gambar ini adalah Lyrical yaitu gambar yang menunjukkan obyek-obyek realis atau nyata yang digambarkan statis. Hal ini ditunjukkan dengan gambar rumah yang diikuti dengan gambar tumbuhtumbuhan serta kesan suasana siang hari dengan gambar awan dan matahari.

Jenis lain pada gambar ini yaitu X-Ray (transparan), yaitu ditunjukkan dengan gambar bunga dan pohon yang seharusnya akarakarnya berada di dalam tanah atau tidak terlihat, tetapi pada gambar ini tetap diperlihatkan.

\section{g. Deskripsi}

Gambar yang saya analisis bertemakan perumahan, simbol yang terdapat pada gambar ini adalah simbol waktu yang menunjukkan siang hari berupa gambar matahari dan awan. Dalam hal garis, pada gambar ini garis masih terlihat raguragu yang ditandai dengan banyaknya bekas hapusan karena garis awal yang salah. Penggunaan warna yang terdapat pada gambar ini harmonis yaitu sesuai dengan kenyataan seperti bunga berwarna merah dan daun berwarna hijau.Dilihat dari komposisi, gambar ini hanya memiliki dua dari tiga unsur pokok komposisi, yaitu kesatuan yang ditunjukkan dengan adanya gambar bunga yang diiikuti dengan gambar pohon serta gambar matahari yang diikuti dengan gambar awan. Unsur yang kedua yaitu keseimbangan yang simetris ditunjukkan dengan posisi gambar bunga dan pohon yang mengisi bagian kiri dan kanan. Tipe dari gambar yang saya analisis adalah tipe visual. Ini dibuktikan dengan gambar anak yang bertema perumahan dengan adanya gambar rumah dan halamannya sesuai dengan apa yang sering dilihat oleh si anak. Gambar ini merupakan salah satu karya seni lukis sederhana, yang jenis gambarnya yaitu lyrical yang ditunjukkan dengan gambar rumah yang diikuti dengan gambar tumbuh-tumbuhan serta kesan suasana siang hari dengan gambar awan dan matahari serta $\mathrm{x}$-ray yang ditunjukkan dengan gambar bunga dan pohon yang seharusnya akar-akarnya berada di dalam tanah atau tidak terlihat, tetapi pada gambar ini tetap diperlihatkan.

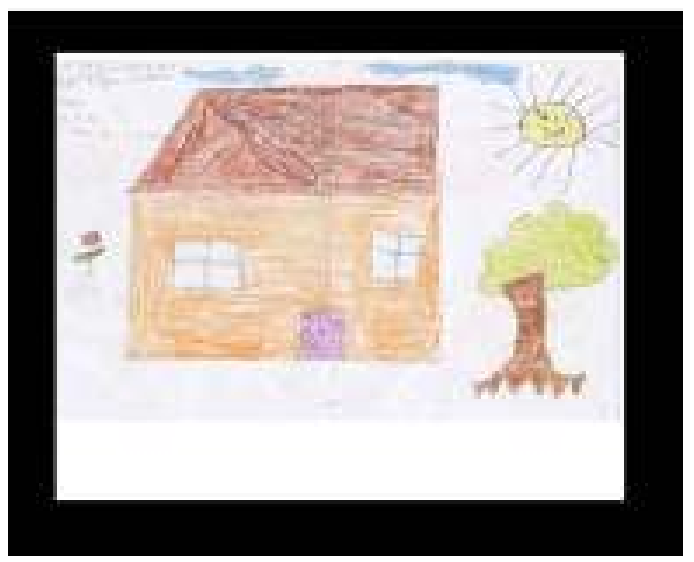




\section{Gambar 4 \\ Karya Syahlaa}

2. Nama : Muhammad Rifal

Usia : 8 tahun

L/P : Laki-laki

Tema :

Pada gambar anak menggambar keadaan gunung dan sekitarnya maka dapat dikatakan bahwa tema gambar yang anak buat adalah pemandangan.

a. Bentuk/Simbol

Dalam gambar ini terdapat empat buah bentuk elips atau lebih menuju lonjong dengan garis tidak lurus di atas gunung yang melambangkan awan. Gunung dan pohon melambangkan kekuatan.

b. Garis

Menurut sifanya dalam gambar terdapat garis nyata dalam gambar rumah, mobil, gunung, matahari, dan pohon. Sedangkan untuk jalan dan awan merupakan garis semu. Serta untuk garis-garis dalam gambar anak menggunakan garis spontan karena tidak menggunakan alat bantu saat menggambar.

c. Warna/Makna

Pada gambar, anak menggunakan warna ungu untuk langit, sebagian dari rumah dan mobil, warna ungu termasuk ke dalam warna dingin karena memberikan kesan tenang, kelembutan, sejuk, dan nyaman. Kemudian untuk warna merah digunakan pada tanah disebelah kiri dipadukan dengan warna hitam, warna merah juga digunakan pada sebagian warna mobil dan rumah. Selain dipadukan dengan warna merah, warna hitam juga muncul pada tanah di gambar sebelah kanan dan pada jalan.

Warna merah yang berarti simbolis dari api, panas, marah, bahaya, aksi, gagah, berani, dan hidup. Warna hijau pada gunung dan daun pada pohon melambangkan kesejukan, dan kehidupan. Matahari berwarna kuning melambangkan imajinasi yang tinggi. Untuk awan anak tidak mewarnainya, warna awan sendiri merupakan warna asli dari kertas yang digunakan menggambar yaitu putih yang berarti suci, bersih, dan jujur. Dan warna cokelat pada batang pohon melambangkan hangat, membumi dan stabil.

d. Komposisi

Komposisi pada gambar ini dalam hal kesatuan merupakan paduan unsur-unsur rupa yang satu dengan yang lain saling menunjukkan adanya hubungan atau keterkaitan terbukti dengan adanya jalan yang dilalui oleh mobil-mobil, disekitar pegunungan terdapat banyak pohon, matahari terbit di balik gunung. Dari hal keseimbangan termasuk kedalam pola keseimbangan asimetris karena menggambarkan kesan dinamis dan tidak formal. Fokusnya tidak terletak di tengah-tengah dan unsur-unsur lain diletakkan secara bebas, namun kesan keseimbangan tetap ada. Dalam gambar terdapat irama dalam variasi ukuran mobil dan pohon.

e. Tipe

Gambar ini termasuk ke dalam tipe realistis, karena gambar mudah diidentifikasi serta bentuknya yang tersusun sesuai dengan apa yang dia ketahui dengan kata lain anak berusaha untuk menampilkan subjek dalam suatu karya sebagaimana tampil dalam kehidupan sehari-hari tanpa tambahan embel-embel atau interpretasi tertentu. 
f. Jenis

Dari adanya pengulanganpengulangan objek, yaitu pohon. Maka gambar ini termasuk ke dalam jenis pola rytmis.

g. Deskripsi

1) Dari analisis yang telah dilakukan dari gambar anak tersebut terdapat sebuah makna yaitu menceritakan keadaan gunung saat ini, tanah di keruk oleh truk-truk dan keadaan gunung menjadi gersang terlihat dari perbandingan warna tanah di sebelah kanan dan kiri, tetapi anak juga masih mengharapkan pegunungan kembali seperti semula yang tercermin dengan langit berwarna ungu. Biasanya pada anak laki-laki usia delapan tahun yang menjadi objek gambar adalah suasana perang, mobil, perahu, tokoh kartun/animasi.

2) Menurut Viktor Lowenfeld dan Lambert Britain gambar anak ini termasuk ke dalam masa bagan.

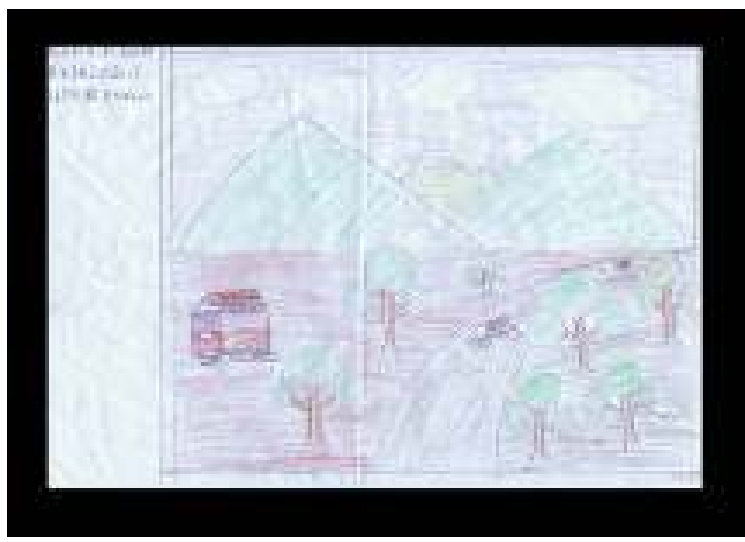

Gambar 5

Karya Muhammad Rifal

3. Nama : Annisa Wulan

Usia : 8 tahun

$\mathrm{L} / \mathrm{P} \quad$ : Perempuan

Tema : Lingkungan rumah

a. Bentuk/Simbol

Bentuk rumah itu sendiri persegi dengan atap atau genteng rumah, di rumah tersebut terdapat dua kaca jendela yang terbuka, dan satu pintu serta satu pintu pagar, bentuk tersebut umumnya beraturan. Bentuk-bentuk objek pada gambar, seperti rumah, pohon, awan, matahari dan burung termasuk dalam bentuk yang sederhana dan familiar dalam gambar-gambar anak. Namun, pada pintu pagar terdapat yang sedikit berbeda, yaitu terdapat nomor 13 .

b. Garis

Garis-garis yang ada pada gambar terlihat spontan dan tegas, tidak terlihat keraguraguan dalam garis-garisnya.

c. Warna/Makna

Warna rumah terdiri dari beberapa warna, yaitu merah muda atau pink pada dinding, cokelat pada genteng, dan warna pintu adalah biru tua serta warna merah pada pintu pagar. Warna yang terlihat dominan pada bangunan rumah tersebut adalah warna pink, sehingga memberikan atmosfer energi muda pada rumah tersebut, warna pink juga menggambarkan sifat yang kekanak-kanakan, dan warna pink merupakan simbol kasih sayang dan cinta, sehingga menimbulkan kesan lembut dan menenangkan. Lalu, ada rerumputan dengan pohon yang dominan berwarna hijau yang bermakna warna alam yang menyegarkan, membangkitkan energi dan juga memberi efek menenangkan, menyejukkan di sekitar rumah tersebut. Warna hijau pada rerumputan dan pohon juga memberi rasa aman dan perlindungan. Tanah yang digambarkan dengan warna coklat bermakna bahwa warna coklat tersebut menggambarkan 
kesuburan tanah. Cokelat, merupakan warna tanah, memiliki karakter yang mampu memunculkan kesan nyaman, stabil, hangat, akrab. Warna biru tua pada pintu melambangkan keamanan, kebersihan dan keteduhan. Warna pagar yang orange menggambarkan karakter hangat, penuh semangat, segar, ceria, dan dapat menciptakan suasana keakraban dan persahabatan. Pintu pagar yang berwarna merah memunculkan kesan energik, berkemauan keras dan keberanian. Langit dan awan-awan yang dominan dengan warna biru bermakna langit yang cerah. Warna kuning dalam warna matahari bermakna cerah, membangkitkan energi dan mood. Warna kuning pada matahari memiliki arti penuh semangat.

\section{d. Komposisi}

Komposisi pada gambar yang saya kaji adalah simetris, karena pada gambar tersebut objek-objek digambarkan dengan keseimbangan, pada gambar bangunan rumah terlihat seimbang dengan objekobjek lainnya, yaitu atap dan jendela yang digambarkan dengan ukuran sesuai, hanya pintu rumah digambarkan dalam ukuran yang kurang sesuai tingginya.

e. Tipe

Tipe gambar anak adalah tipe non haptik atau realistis karena bentuk dari gambar ini, mudah untuk diidentifikasi dengan bentuk-bentuk objek yang sederhana, yaitu bentuk rumah yang sederhana, bentuk pohon yang sederhana, serta matahari dan awan-awan serta burung yang sederhana.

f. Jenis

Gambar ini cenderung bergaya structural form/bentuk bersusun, terdapat empat susunan yaitu, tanah terdapat di paling bawah, tanah dengan warna cokelat di bagian kedua, rumah dan rumputrumput di susunan ke tiga, dan langit pada susunan paling atas. Dalam gambar ini terdapat beberapa pengulangan objek, seperti rumput yang digambar berulang-ulang dengan bentuk yang sama, burung-burung dengan pengulangan bentuk yang sama, sehingga gambar ini berpola rytmis atau pengulangan.

Ruang (space) pada gambar ini terlihat jarak dari suatu objek dengan objek yang lainnya tidak terlalu berdekatan dan tidak terlalu berjauhan, seperti antara rumah dengan pohon berada pada ruang yang tepat, matahari dan awan dalam ruang yang tepat sehingga memberikan efek keindahan pada gambar.

\section{g. Deskripsi}

Gambar ini bertemakan lingkungan rumah, di sana terdapat satu bangunan rumah dengan pohon yang terletak di samping rumah, rerumputan yang ada di sekeliling rumah, serta dengan awan-awan di langit, matahari yang bersinar dan burung-burung yang berterbangan. Gambar ini termasuk dalam gambar anak masa bagan yaitu berlaku bagi anak berusia 7 sampai 9 tahun. Di dalam gambar, anak sudah mulai menggambar obyek dalam suatu hubungan yang logis dengan gambar lain. Apa yang digambar oleh anak mulai realistis dan mulai mengarah ke bentukbentuk yang mendekati kenyataan. Menurut saya, gambar ini dibuat anak berdasarkan ide anak sendiri, seperti gambar jendela pada rumah tersebut dengan kaca yang terbuka, tetapi apa yang anak 
gambar cenderung lebih banyak mencontoh dari gambar-gambar pada umumnya.

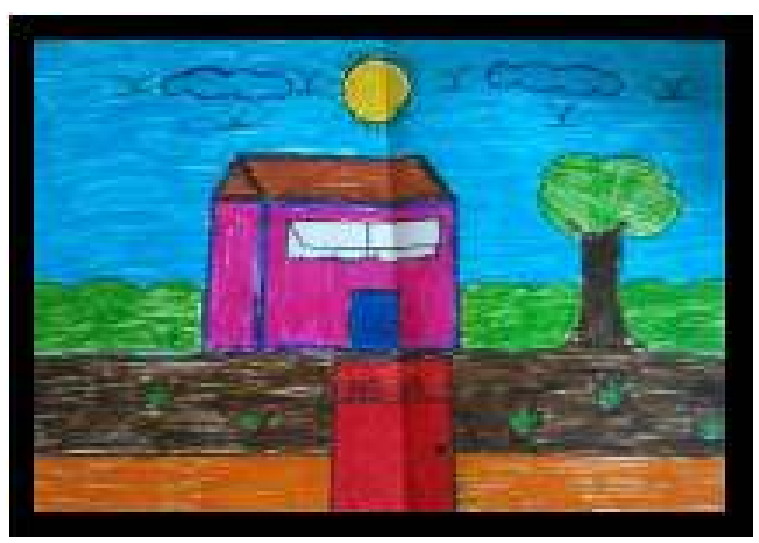

Gambar 6

Karya Annisa Wulan

\section{Analisis Gambar Karya Anak Usia 9 Tahun}

1. Nama : Fajar

Usia : 9 tahun

L/P : Laki-Laki

Tema : Berlibur ke pantai

\section{a. Bentuk/Simbol}

Sesuai dengan karakteristik anak usia sekolah. Dengan rentang usia 69 tahun, dan jenis kelamin laki-laki, Fajar telah memperlihatkan kecenderungan menggambar yang tepat untuk anak laki-laki seusianya yaitu menggambar perahu.

Bentuk pada gambar anak sudah menyerupai gambar seperti bentuk yang seharusnya. Seperti kapal, rumah, layang-layang, awan, burung, matahari, pohon, ikan, laut, daratan dan orang, walaupun tidak akurat persis sama dengan aslinya, namun setidaknya ia menggambar dari wujud pengamatannya dan pemahamannya terhadap benda, atau situasi yang ada di sekitar kehidupan dia yang dilihat sendiri dengan mengekspresikan ide kebentukan benda sendiri. Usia 7-9 termasuk kedalam usia bagan yaitu usia dimana konsep bentuk sudah mulai jelas. Anak cenderung mengulang bentuk. Gambar masih tetap berkesan datar dan berputar atau rebahan.Begitupun terlihat dari gambar Fajar, dia mengulang bentuk orang, ikan dan burung, konsep bentuk sudah mulai jelas, gambarnya pun masih berkesan datar.

Simbol. Dari gambar Fajar, terlihat gambar perahu lebih besar dari objek yang lain. Bisa saja anak menyimbolkan bahwa dia ingin lebih menunjukan dia adalah anak laki-laki. Karena anak laki-laki mempunyai kecenderungan menggambar perahu, mobil, tokoh kartun atau suasana perang. Sedangkan anak perempuan mempunyai kecenderungan menggambar rumah, orang (putri), bunga, pohon, matahari dsb. Maka dari itu gambar perahu lebih besar ia gambar dibandingkan dengan gambar-gambar yang lain, yang biasanya anak perempuan gambar.

Gambar ikan lebih besar dibandingkan gambar manusia, mungkin dia sangat menyukai ikan dan ikan itu adalah makanan yang bermanfaat untuk kesehatan manusia. Sehingga ia banyak menggambar orang yang sedang meancing ikan.

Selain itu, ada beberapa makna dari gambar anak yang dapat menyimbolkan sifat atau keadaan anak. Seperti,

1) Perahu (alat transportasi. Gambar alat transportasi dalam bentuk apa pun melambangkan hasrat untuk pergi atau mencapai tujuan.

2) Rumah. Coretan ini banyak digambar perempuan. Gambar ini menunjukkan perasaan terhadap lingkungan rumah. Ada jalan di depan pintu rumah dan 
beberapa rerumputan disekitar rumah. Mungkin ia sangat nyaman dengan kondisi rumahnya.

3) Burung. Gambar burung, artinya ia memiliki daya imajinasi yang tinggi, penuh pertimbangan, cinta kasih, dan menyukai kebebasan.

4) Manusia. Sangat senang bersosialisasi dan berada pada lingkungan yang ramah dengan orang-orang disekitar.

5) Pohon. Gambar ini melambangkan ego dan ambisi. Jika pohon itu memiliki daun yang lebat dan buah, ini menunjukkan Anda orang yang mendambakan cinta.

6) Benda Langit. Gambar bintang dan benda-benda langit menunjukkan perasaan penuh harapan, optimisme, ambisi dan kebutuhan untuk membuktikan serta mempromosikan diri.

b. Garis

Garis yang terdapat pada gambar fajar adalah garis yang tipis dan patahpatah biasanya goresan tipis dan patahpatah dapat ditafsirkan bahwa si penggambar memiliki jiwa dan emosi yang tidak stabil atau raguragu. Biasanya orangnya minder, penakut, dan kurang percaya diri.Atau bisa juga dia mempunyai keraguan, ketakutan dan tekanan berekspresi.

Garis dan coretan yang terdapat pada gambar fajar adalahcoretan campuran dan dominan melengkunglengkung. Jika coretan anak bercampur baur, ada bulatan, segitiga, segiempat, namun didominasi garis melengkunglengkung, berarti anak butuh kebebasan dan eksplorasi diri.

Dari sisi karakter biasanya ia kreatif, mencintai seni, suka mengekspresikan sesuatu lebih terbuka, mencoba hal-hal baru, ekspresionis, dan lainnya.

Sayangnya biasanya ia sulit diatur, keras kepala, semaunya sendiri, dan lainnya.

Imajinasi merupakan motivasi utama dalam dirinya. Mereka adalah orang-orang yang tidak suka rutinitas, kurang peduli terhadap ketepatan waktu, protokoler, dan keseragaman. Mereka memiliki kebutuhan untuk mencipta (innovator). Anak mempunyai jiwa seni yang tinggi.

Umumnya ia adalah anak yang superunik dan jiwa seninya yang tinggi, cenderung berfikir out of the box. Gagasannya sangat kreatif dan sulit di duga, berbeda dari orang kebanyakan.

c. Warna dan Makna

Pada gambar Fajar terdapat beberapa warna, yaitu warna biru muda, ungu, merah, kuning, hijau dan orange.

1) Biru Muda. Warna ini melambangkan keanjalan dari cita-cita. Sifatnya bertahan, protektif, tidak berubah pikiran. Pengaruhnya: Keras Kepala; Teguh; Sering Bangga Diri; dan Berpendirian tetap. Respon Psikologi: Kepercayaan; Konservatif; Keamanan; Teknologi; Kebersihan; dan Keteraturan. Catatan: Banyak digunakan sebagai warna pada logo Bank di Amerika Serikat untuk memberikan kesan "kepercayaan".

2) Ungu. Warna ini adalah campuran warna merah dan biru yang melambangkan sifat gempuran keras yang dilambangkan oleh warna biru. Perpaduan antara keintiman dan erotis atau 
menjurus pengertian yang mendalam dan peka. Sifatnya sedikit kurang teliti tetapi selalu penuh harapan. Respon Psikologi, berarti spiritual, misteri, kebangsawanan, transformasi, kekasaran, dan keangkuhan. Catatan, warna ungu sangat jarang ditemui di alam.

3) Merah. Warna ini melambangkan kekuatan kemauan atau cita-cita. Sifatnya agresif, aktif, dan eksentrik. Pengaruhnya, berkemahuan keras, penuh gairah, dominasi, jantan.

4) Kuning. Warna ini melambangkan kegembiraan. Warna ini mempunyai sifat leluasa dan santai, senang menunda-nunda masalah. Berubah-ubah tapi penuh harapan, mempunyai cita-cita setinggi langit dan semangatnya juga tinggi.

5) Oranye. Menunjukkan kehangatan, antusiasme, persahabatan, pencapaian bisnis, karir, kesuksesan, kesehatan pikiran, keadilan, daya tahan, kegembiraan, gerak cepat, sesuatu yang tumbuh, ketertarikan, independensi. Pada Blog dapat meningkatkan aktifitas mental. Disamping itu warna oranye memberi kesan yang kuat pada elemen yang dianggap penting.

\section{d. Komposisi}

Komposisi dari keseluruhan gambar fajar sudah seimbang semua kertas terisi. Di laut, terdapat benda dan hewan yang berada di laut, seperti ikan dan perahu, di langit terdapat burung dan benda langit lainnya seperti matahari dan awan. Begitupun di darat terdapat rumah, rumput, pasir, pohon kelapa dan orang (anak-anak yang sedang bermain layangan dan memancing).
Kesan yang diberikan dari gambar fajar adalah kehatan dan sosialisasi yang ada di pesisir pantai yang sedang berlibur dan menikmati liburannya dengan memancing dan bermain layangan.

e. Tipe

Penggolongan type gambar menurut Victor Lowenfeld adalah tipe haptik dan tipe visual.

Gambar yang dibuat oleh Fajar menunjukan kepada type campuran antara haptik dan visual. Karena jika type visual gambar yang dibuat sesuai dengan proporsinya tidak ada yang lebih besar dari seharusnya.Sedangkan gambar haptik terdapat hal yang tidak realistis. Dalam gambar fajar ada beberapa gambar yang dibuat dengan proporsi yang pas dan detail, seperti rumah, pohon dan jalan di depan rumah yang berbatu. Namun hal yang tidak realistis adalah manusia yang lebih besar dari ikan, juga kapal laut yang lebih jelas dan besar dibandingkan dengan objek yang lainnya. Mungkin ia menyukai kapal dan ikan, dan menurutnya kapal dan ikan lebih penting.

f. Jenis

Dalam In Education Through Art, Read (1958: 140) mengklasifikasikan gambar anak-anak menjadi 12, yaitu: Organic, Lyrical, Impresionist, Rhytmical Pattern, Structur Form, Shematic, Haptic, Expresionist, enumeratif, Decorative, Romantic, dan Literari.

Gambar yang dibuat oleh Fajar termasuk kedalam type organic, berkaitan serta bersimpati dengan objek-objek nyata, anak-anak lebih suka 
objek dalam kelompok daripada yang sendiri. Tipe ini juga mengenal proporsi yang wajar dan hubungan organis yang wajar pula. Seperti ikan yang hidup di air, pohon kelapa menjulang di atas pasir, burung di udara, dan manusia bergerak seperti mestinya memancing dan bermain layangan.

\section{g. Deskripsi}

Gambar yang dibuat oleh fajar termasuk kedalam sifat gambar cerita (naratif). Gambar tersebut bercerita ketika berlibur dipantai, bermainmain dan memancing. Lukisan/gambar yang merupakan ungkapan perasaan atau gejolak jiwa, bukan sekedar mencoret sebagai aktivitas motorik atau gerak anatomis saja. Maka perlu ditanggapi secara wajar dan dalam sikap menerima serta mengahargai.

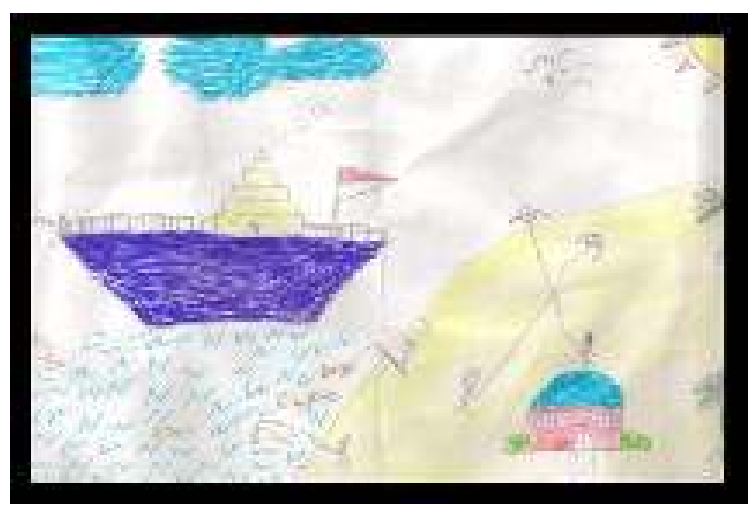

Gambar 7

Karya Fajar

2. Nama : Putri

Usia :9 Tahun

L/P : Perempuan

Tema : Gunung berapi

a. Bentuk/Simbol

1) Bulan

Bulan yang berbentuk bulat dan sangat kecil di belakang gunung, menunjukan bahwa bulan tersebut sudah kurang terlihat karena tertutup asap-asap yang berasal dari gunung berapi.

2) Gunung
Gunung berapi yang berjumlah satu dan besar berbentuk segitiga yang termasuk ke dalam jenis gunung berapi kerucut atau strato, menunjukan bahwa gunung tersebut akan mengeluarkan letusan yang sangat dashyat karena pada puncak gunungnya sudah mengeluarkan lava.

3) Awan

Awan pada gambar ini berjumlah lima, bentuk dan ukuran yang hampir sama.

4) Bintang

Bintang berjumlah dua yang kurang terlihat namun bentuk sangat jelas.

5) Rumah

Anak ini menggambar rumah yang kecil agar membuat kesan yang sesuai dengan rumah pedesaan di bawah kaki gunung yang rumahnya dikelilingi oleh kebun.

6) Sawah

Sawah yang diletakan di pojok kiri bawah, dimana anak pada umumnya selalu menggambar sawah di bawah kaki gunung.

7) Kebun

Kebun yang diletakan di bawah kaki gunung, agar membuat kesan pedesaan di bawah kaki gunung yang indah dipenuhi dengan tumbuhan-tumbuhan.

8) Lapangan

Lapangan di pedesaan yang kosong disebabkan karena desa tersebut sudah tidak aman dan anak-anak beserta keluarganya yang ada di desa tersebut sudah mengungsi ke tempat yang lebih aman.

9) Pohon 
Ada dua pohon besar di samping kiri dan samping kanan gunung, anak tersebut membuatnya di kaki gunung agar bisa menjadi tempat berteduh ketika panas atau hujan.

b. Garis

Garis pada gambar yang dibuat siswi SD ini bersifat spontan, dimana siswi ini membuat garis secara spontan tidak ragu-ragu dalam membuat setiap bentuknya. Kebanyakan anak yang membuat gambar dengan garis spontan bersifat tegas, tidak ragu- ragu dan percaya diri.

\section{c. Warna}

Langit. Meskipun sudah malam dan ada gunung berapi pada gambar ini, langitnya berwarna biru, mungkin disebabkan oleh anak perempuan yang ingin selalu mengutamakan pemandangan yang indah.

Bulan. Bulan berwarna oranye, anak ingin menunjukan bahwa bulan selalu menerangi bumi dimanapun walaupun di tempat yang bersuasana buruk dan mencekam.

Gunung. Gunung berapi berwarna hijau, warna yang kurang tepat dengan tema gunung berapi, yang seharusnya berwarna gelap. Hal ini sebabkan oleh anak putri yang selalu ingin menggambar dengan kesan pemandangan yang indah.

Pohon. Warna dedaunan pohon yang hijau dan batang berwarna cokelat yang membuat kesan bahwa pohon tersebut teduh untuk didiami.

Awan. Awan berwarna biru ketika dimalam hari agar membuat kesan pada gambar tersebut cerah.

Bintang. Sama dengan anak putrid pada umumnya yang menggambar dengan warna cerah agar kesan indah tidak hilang.

Sawah. Berwarna cokelat dan padi-padinya berwarna kuning gelap, menunjukan bahwa padi-padi di sawah tersebut sudah siap dipanen namun tidak ada orang yang memanen padi tersebut, karena seluruh warga desa sudah pergi mengungsi ke tempat yang lebih aman.

Kebun. Rumput di kebun yang berwarna hijau dan bunga yang berwarna merah. Sesuai dengan karakteristik anak putri yang menggambar bunga dengan warna cerah.

Rumah. Rumah berwarna oranye, atap berwarna biru agar terkesan rumah tersebut indah, juga jendela berwarna kuning yang menunjukan bahwa di dalam rumah lampu sedang menyala di malam hari.

Lapangan. Berwarna cokelat yang berarti menghadirkan kenyamanan, dimana anak-anak selalu nyaman ketika bermain dilapangan ini.

\section{d. Komposisi}

Gambar yang dibuat oleh siswi ini komposisi nya sudah cukup tepat dengan tema seperti burung yang menjauh dari gunung berapi dan tidak menghilangkan karakteristik anak perempuan yang selalu menggambar bunga, pepohonan dan pemandangan yang indah.

e. Tipe

Tipe gambar yang dibuat oleh siswi ini bertipe non haptik/ realistis karena gambar tersebut lebih mengutamakan kejelian bentukbentuknya daripada mengutamakan perasaan atau pikiran tanpa memperhatikan bentuk, sehingga gambar ini lebih mudah diidentifikasi oleh orang lain.

f. Jenis 
Gambar ini berjenis enumerative karena seperti sebuah potret ketika gunung berapi akan meletus,pada gambar ini juga terdapat pola rytmis dimana ada pengulangan objek seperti padi di sawah, bunga-bunga di kebun dan pohon di samping kaki gunung.

\section{g. Deskripsi}

Anak berusia 9 tahun termasuk ke dalam masa bagan, dimana anak mampu menggambar bentuk dan warna objek cenderung sesuai dengan aslinya, meskipun bila diamati masih ada bagian-bagian yang masih kurang sesuai dengan aslinya. Gambar ini juga sesuai dengan karakteristik anak putri seperti menggambar bunga, pohon, dan pewarnaan yang cerah meskipun dengan tema gunung berapi yang seharusnya gunung berwarna gelap dan langit yang seharusnya berwarna gelap ketika di malam hari.

Menurut siswa tersebut, gambar ini bertema Gunung berapi, namun kesan yang terdapat di dalam gambar warna gunung kurang tepat dengan tema gunung berapi yang pada umumnya gunung berapi berwarna gelap dan tidak berwarna terang seperti hijau., langit yang masih cerah walaupun malam yang seharusnya gelap karena tertutup asap dari gunung berapi tersebut. Tetapi ada beberapa bagian yang sudah tepat seperti puncak gunung yang berwarna merah, burungburung yang menjauh dari gunung karena akan meletus.

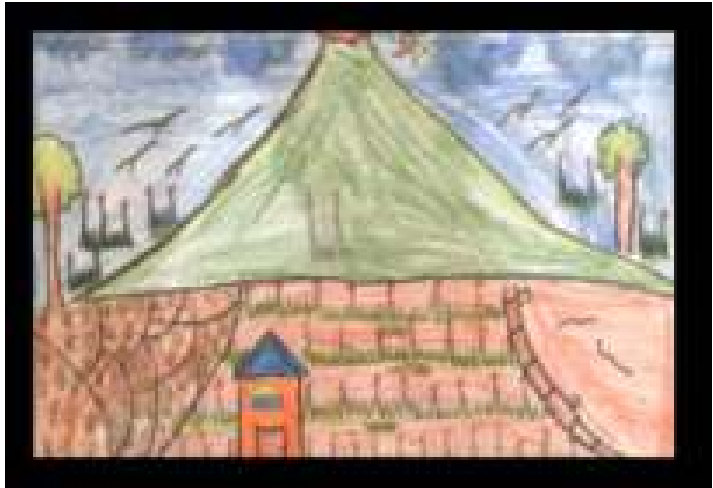

\section{Gambar 8}

Karya Putri

3. Nama : Putri

Usia : 9 tahun

$\mathrm{L} / \mathrm{P} \quad: \mathrm{P}$

Tema : Pemandangan

a. Bentuk atau simbol

Disini bisa kita lihat bahwa bentuk yang anak gambar termasuk ke dalam bentuk nongeometris, itu dikarenakan bentuk nongeometris berupa bentuk yang meniru bentuk alam, misalnya manusia, tumbuhan dan hewan.

b. Garis

Pada gambar ini terlihat garis yang ada itu spontan dan menggunakan garis lengkung karena terkesan lembut dan lentur juga dia buat tanpa ragu ragu sehingga tidak terlihat kaku.

c. Warna/Makna

Teknik pewarnaan disini anak cenderung belum berani dalam mencampurkan warna.Dia hanya menggunakan satu warna dalam satu objek. Warna yang digunnakan tergolong kedalam warna primer dan warna sekunder.

Matahari disini diberi warna oranye dalam setengah lingkarannnya sedangkan kuning di luar bulatan tersebut dan juga dijadikan sebagai warna langit dan bunga. Mungkin disini 
maksud dari anak adalah keadaan waktu senja. Warna ini tergolong kedalam kategori warna hangat. Dalam artian warna ini berani dan energik. Menghangatkan maksudnya orang - orang yang cenderung berfikir dan bergerak. Jika perlu elemen pop dalam seni lukis, pertimbangkan untuk menggunakan pengertian warna hangat di dalamnya seperti warna kuning, oranye, cokelat, dan hijau kekuning kuningan dan merah muda. Warna kuning disini juga adalah warna matahari, cerah, membangkitkan energi dan mood, warna yang penuh semangat dan vitalitas, komunikatif dan mendorong ekspresi diri, memberi insprirasi, memudahkan pikiran secara logis dan merangsang kemampuan intelektual. Warna orange juga punya karakter yang mirip dengan merah tapi lebih feminim dan bersahabat. Warna yang melambangkan sosialisasi, penuh harapan dan percaya diri, membangkitkan semangat, vitalitas dan kreatifitas. Dapat menimbulkan perasaan positif, senang, gembira dan optimis, penuh energi, bisa mengurangi depresi/perasaan tertekan. Bila berlebihan justru akan merangsang prilaku hiperaktif.

Awan disini diberikan warna biru. Warna biru memberikan kesan komunikasi, peruntungan yang baik, kebijakan, perlindungan, inspirasi spiritual/kepercayaan, konservatif, keamanan, teknologi, kebersihan, keteraturan, tenang, kelembutan, dinamis, air, laut, kreativitas, cinta, kedamaian, kepercayaan, loyalitas, kepandaian, panutan, kekuatan dari adlam, kesedihan, kestabilan, kepercayaan diri, kesadaran, pesan, ide, berbagi, idealisme, persahabatan dan harmoni, kasih sayang. Warna ini memberi kesan tenang dan menekankan keinginan. Biru tidak meminta mata untuk memperhatikan.
Obyek dan gambar biru pada dasarnya dapat menciptakan perasaan yang dingin dan tenang. Warna biru juga dapat menampilkan kekuatan teknologi, kebersihan, udara, air dan kedalaman laut. Selain itu, jika digabungkan dengan warna merah dan kuning dapat memberikan kesan kepercayaan dan kesehatan. Arti positif, keheningan, mencintai, kesetiaan, keamanan, percaya, intelligence, sedangkan arti negatif: kedinginan, ketakutan, kejantanan.

Gunung, daun, sawah, rumput, dan pohon diberikan warna hijau. Mungkin diberikan warna hijau karena warna hijau memiliki makna menunjukkan warna bumi, penyembuhan fisik, kelimpahan, keajaiban, tanaman dan pohon, alami, sehat, keberuntungan, kesuburan, pertumbuhan, muda, kesuksesan materi, pembaharuan, daya tahan, keseimbangan, ketergantungan dan persahabatan. Dapat digunakan untuk relaksasi, menetralisir mata, memenangkan pikiran, merangsang kreatifitas. Arti positif, uang, pertumbuhan, kesuburan, kesegaran, healing, sedangkan arti negatif, iri hati, kecemburuan, kesalahan, kekacauan.

Awan berwarna biru beserta air yang mengalir dari hulu gunung. Warna biru ini memberikan kesan komunikasi, peruntungan yang baik, kebijakan, perlindungan, inspirasi spiritual/kepercayaan, konservatif, keamanan, teknologi, kebersihan, keteraturan, tenang, kelembutan, dinamis, air, laut, kreativitas, cinta, kedamaian, kepercayaan, 
loyalitas, kepandaian, panutan, kekuatan dari adlam, kesedihan, kestabilan, kepercayaan diri, kesadaran, pesan, ide, berbagi, idealisme, persahabatan dan harmoni, kasih sayang. Warna ini memberi kesan tenang dan menekankan keinginan. Biru tidak meminta mata untuk memperhatikan. Obyek dan gambar biru pada dasarnya dapat menciptakan perasaan yang dingin dan tenang. Warna biru juga dapat menampilkan kekuatan teknologi, kebersihan, udara, air dan kedalaman laut. Selain itu, jika digabungkan dengan warna merah dan kuning dapat memberikan kesan kepercayaan dan kesehatan. Arti positif, keheningan mencintai, kesetiaan, keamanan, percaya, intelligence, sedangkan arti negative, kedinginan, ketakutan, kejantanan.

Dan yang terakhir disini terdapat bebatuan yang diberi warna cokelat. Warna cokelat ini menunjukkan persahabatan, kejadian yang khusus, tanah/bumi, pemikiran yang materialis, reliabilitas, kedamaian, produktivitas, praktis, kerja keras, kepercayaan, daya tahan, kesenangan. Warna coklat sangat tidak menarik apabila digunakan tanpa tambahan gambar dan ornamen tertentu. Cokelat harus didukung ornamen lain agar menarik. Arti positif: ramah, bumi, keluar rumah, umur panjang, konservatif, sedangkan arti negatif, dogmatis, konservatif.

\section{d. Komposisi}

Komposisi gambar ini sudah cukup tepat penempatan gambarnya.Karena kita sudah terbiasa bila melihat gunung pasti disertai sawah dan beberapa aliran sungai yang mengalir. Di sini juga sang anak tidak lupa menambahkan beberapa pohon.

e. Tipe
Penggolongan karya gambar anak ini menurut Victor Lowenfeld termasuk ke dalam tipe Visual. Tipe visual adalah gambar anak yang menunjukkan kecenderungan bentuk yang lebih visual-realistis (memperlihatkan kemiripan bentuk gambar sesuai obyek yang dilihatnya, atau obyektif). Gambar yang diungkapkan mementingkan kesamaannya karya dengan bentuk yang diahayatinya serta memperhitungkan proporsinya secara tepat. Penguasan ruang telah terasa dengan cara membuat kecil objek gambar bagi benda yang jauh. Begitupula penguasaan warna, pemakaian warna sesuai dengan warnawarna pada bendanya.

Sifat. Gambar ini bersifat simetris (setangkep) karena dalam menggambar suatu objek sering timbul gejala untuk melukis hal-hal yang asimetris menjadi asimetris. Misalnya, dua buah gunung kembar dengan matahari di tengah, setangkai bunga dengan daun kiri dan di kanan.

f. Jenis

Menurut In Education Through Art, Read (1958: 140) penggambaran objek bersifat realistis, tetapi tidak bergerak seperti organic juga objek yang digambarkan statis. Pada gambar ini juga terdapat pola rytmis dimana ada pengulangan objek seperti padi di sawah, bungabunga di kebun dan beberapa pohon di bawah kaki gunung.

\section{g. Deskripsi}

Anak berusia 9 tahun termasuk ke dalam masa bagan, dimana anak mampu menggambar bentuk dan warna 
objek cenderung sesuai dengan aslinya. Menurut Lansing (Kamaril: 1999:2.38) periode perkembangan anak - anak ini tergolong kedalam pertengahan figuratife tetapi menurut Viktor Lowenfeld dan Lambert Britanny termasuk ke dalam masa realism awal. Dalam gambar ini menggambarkan daerah persawahan yang diapit oleh dua pegunungan yang tinggi dimana di tengah tengah gunung tersebut ada setengah matahari. Mungkin disini suasananya saat senja tiba, dikarenakan gambar matahari tersebut dalam keadaan setengah tenggelam. Disini juga terlihat ada air sungai yang mengalir dari hulu gunung. Kemungkinan di gambar ini ada semacam kebun atau mungkin hutan. Ada beberapa pohon cemara disertai rumput - rumput liar yang tumbuh. Tidak tertinggal disini juga satu pohon kelapa yang tumbuh di antara bebatuan serta beberapa bunga liar. Gambar ini juga sesuai dengan karakteristik anak perempuan seperti menggambar bunga, pohon, dan juga proses pewarnaan yang cerah.

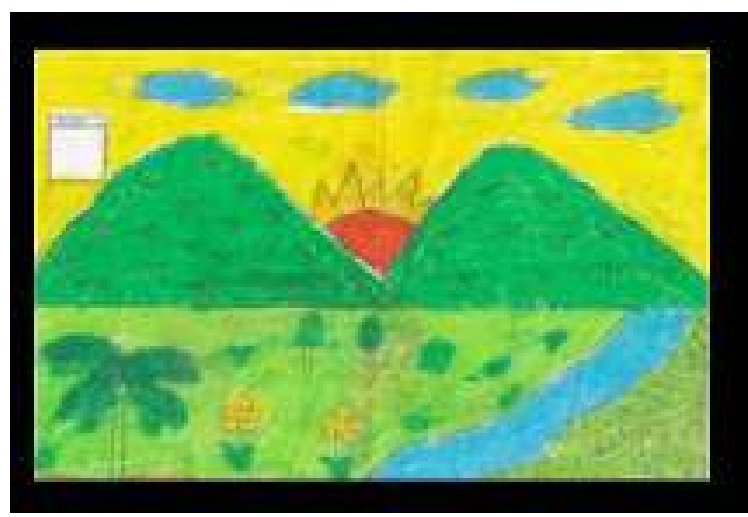

Gambar 9

Karya Putri

\section{E. SIMPULAN DAN SARAN}

\section{Simpulan}

Masa anak-anak paling efektif dalam pengembangan kreativitas. Potensi anak seusia mereka berada pada masa yang amat penting untuk dirangsang perkembangannya. Untuk mendukung kreativitas mereka, perlu tercipta susasana yang menjamin terpeliharanya kebebasan psikologis yang dapat diciptakan dan dipelihara dengan membangun suasana bermain yang dapat melatih dan memberikan kesempatan pada anak untuk menampilkan ide dan gagasan baru secara lancar dan orisinil melalui gambar.

Dalam menganalisis gambar karya anak usia 7 sampai 9 tahun, kita dapat mengetahui fungsi dan karakteristik gambar mereka, seperti memberi kesempatan bagi anak untuk aktualisasi diri atau mengekspresikan perasaan tersebut melalui berkarya seni yang sesuai dengan minat dan taraf perkembangannya.

Salah satu fungsi menggambar ialah dapat memberikan pengenalan dan latihan menggunakan bahasa dan terminologi seni rupa untuk mendeskripsikan dan memberikan tanggapan terhadap karya seni rupa serta melatih kemampuan untuk memahami makna-makna yang disampaikan melalui simbol-simbol visual, bentuk-bentuk, dan metafora.

Gambar anak-anak adalah salah satu karya seni yang dapat atau sebagai media untuk mengetahui perkembangan jiwa anak. Karakteristik gambar karya anak usia 7 sampai 9 tahun sangatlah khas, yang menarik adalah bentuk gambar anak-anak yang unik, yang berbeda dibandingkan gambarnya orang dewasa. Gambar anak-anak memiliki kelebihan, disamping dapat untuk mengamati perkembangan jiwa juga memiliki keistimewaan dalam komposisi, bentuk, dan cara penggambarannya, warna, tipe, jenis, garis, dan tema sehingga menghasilkan pola gambar yang sangat menarik dan unik.

\section{Rekomendasi}

Pembelajaran adalah suatu proses mengembangkan potensi anak didik dengan memberdayakan semua potensi yang dimilikinya sehingga mereka akan 
mampu meningkatkan pemahamannya terhadap fakta, konsep atau prinsip dalam suatu kajian ilmu yang dipelajarinya yang akan terlihat dalam kemampuannya untuk berpikir logis kritis dan kreatif.

Dalam pembelajaran atau mengapresiasi karya, guru sebaiknya menetahui karakteristik gambar/karya anak serta memberikan penghargaan bagi setiap hasil karya yang telah dikerjakan oleh anak, karena hal tersebut akan memberikan dorongan positif bagi anak. Apapun hasil kerja anak merupakan suatu proses yang terus berlangsung ketika anak belajar hingga dapat menghasilkan kepuasan bagi dirinya.

\section{DAFTAR PUSTAKA}

A.AlvesRubem. 2005. Anak Masa Depan .Inisiasi Press. Depok.

B .Elizabeth Hurlock. 1978. Perkembangan Anak. Erlangga Jakarta

Dahlan, Djawad, 2002, Psikologi Perkembangan Anak \& Remaja, PT. Remaja Rosdakarya, Bandung.

Depdikbud.1982. Wawasan Kependidikan Guru. Modul Akta Mengajar VB. Jakarta ;DirjenDikti.

Engkoswara. 1984. Dasar-dasar Metodologi Pengajaran. BinaAksara. Jakarta

Ghiselin, Brewster, 1983, The Creative Process / Proses Kreasi, terj. Wasid Soewarto, Jakarta :Gunung Jati, cetakan I.

Garha. Oho dkk. 1990. Pendidikan Seni Rupa untuk SD. Angkasa . Bandung

G. P.Nanang dkk. 2001. Pendidikan Seni Rupa (untuk mahasiswa PGSD). UPI

--- $\quad$ 2003. Pendidikan Seni Rupa. UPI

Hartati, Tatat. 2010. Practice Pedagogik in Global Education Perspective. UPI Press. Bandung.

Henry P. Mussen. 1984. Perkembangan dan kepribadian Anak. Erlangga Jakarta.
Hermawan, Ruswandi. 2008. Metode Penelitian Pendidikan SD. UPI Press. Bandung.

Mulyasari, Effy. 2011. Pedagogik Praktis yang Berkualitas. Rizqi Press. Bandung.

Munandar Utami. 2004. Perkembangan Kreativitas Anak Berbakat. Pusat Perbukuan Depdiknas. Jakarta.

Nazir, Moh. 2005. Metode Penelitian. Ghalia Indonesia.

Pamadhi Hajar, dkk. 2008. Seni Keterampilan Anak. Universitas Terbuka.

Soemaryadi.1992/1993. Pendidikan Keterampilan. Depdikbud. Direktorat Jendral Pendidikan Tinggi PPTK.

Sumardjo, Jakob. 2000. Filsafat Seni. ITB. Bandung.

Tabrani, Primadi. 1999. Belajar dari sejarah dan lingkungan. ITB. Bandung.

2000. Proses Kreasi, Apresiasi, Belajar. ITB. Bandung.

2005. BAHASA RUPA. ITB. Bandung. Tarjo, E, dkk. (2005). Seni Rupa dan Kerajinan. Bandung: SR UPI 